\title{
The Proteomic Changes in Cynara Cardunculus L. var. altilis DC Following the Etiolation Phenomena Using De Novo Sequence Analysis
}

\author{
Carmine Guarino, ${ }^{1}$ Luciana De Simone, ${ }^{1}$ Simona Santoro, ${ }^{1}$ Simonetta Caira, ${ }^{2}$ Sergio Lilla, ${ }^{3}$ \\ Maria Grazia Calabrese, ${ }^{3}$ Lina Chianese, ${ }^{3}$ and Francesco Addeo ${ }^{3}$ \\ ${ }^{1}$ Department of Biological and Environmental Sciences, University of Sannio, 82100 Benevento, Italy \\ ${ }^{2}$ Institute of Food Science, CNR, Via Roma 52 A/C, 83100 Avellino, Italy \\ ${ }^{3}$ Department of Food Science, University of Naples "Federico II", 80055 Portici, Italy
}

Correspondence should be addressed to Carmine Guarino, guarino@unisannio.it

Received 19 November 2009; Revised 12 April 2010; Accepted 5 May 2010

Academic Editor: Andrea Polle

Copyright ( 12010 Carmine Guarino et al. This is an open access article distributed under the Creative Commons Attribution License, which permits unrestricted use, distribution, and reproduction in any medium, provided the original work is properly cited.

\begin{abstract}
Etiolation of vegetables is a complex phenomenon implying qualitative and quantitative protein changes. The 2-DE protein profile of green and etiolated fleshy stalk samples has shown great differences in the $4-7 \mathrm{pH}$ and 10 to $250 \mathrm{kDa}$ mass range. Currently, a shortage of Cynara DNA or protein sequences has required the use of de novo sequencing and BLAST similarity searches for protein identification. Highlighted herein is an application of proteomics to the identification of proteins, which in a great part matched those from the Viridiplantae order. Quantitative evaluation, statistical analyses, and MALDI-TOF MS characterization of the resolved spots in green and etiolated samples of C. cardunculus enabled us to identify 46 out of 60 spots, containing 21 spots included conserved Viridiplantae domains. The etiolation process is discussed in light of the identification of some proteins involved in specific biochemical and metabolic pathways.
\end{abstract}

\section{Introduction}

In dark-grown angiosperm plants, chlorophyll biosynthesis is arrested at the Pchlide stage (etiolation) due to the deficiency of a light-requiring oxidoreductase enzyme which naturally converts Pchlide to chlorophylls. In parallel, the natural content of fibre, bitter, and aromatic compounds declines in vegetables [1-4]. By and large, the edible portion of plants corresponds to etiolated foliated rosettes or young stalks of biennials or perennials. Transient etiolation of leaves and other tissues takes place naturally during spring development under light-deficit. The same phenomena can be reproduced by transferring plants to a dark chamber at optimal temperature for growth. During etiolation, various biochemical and anatomical processes occur, implying mainly an increased synthesis and accumulation of plastidial proteins. Little information had thus far been available on the expressed plant proteins during etiolation and subsequent deetiolation. A more detailed characterization of vegetable proteins using proteomics is needed for a more comprehensive view of the physiological changes associated to the etiolation process. A deeper understanding of the cellular events is highly desirable also in view of manipulations aimed to improve sensorial, nutritional, and shelf life features.

The cultivated cardoon (Cynara cardunculus L. var. altilis DC) is one of the vegetables most subjected to etiolation. Cynara cardunculus L. is a diploid $(2 n=34)$ out crossing perennial species native to the Mediterranean basin and comprising the globe artichoke (var. scolymus L.), the cultivated cardoon (var. altilis DC), and the wild cardoon (var. sylvestris (Lamk) Fiori). Cynara cardunculus var. sylvestris is considered the wild ancestor of the globe artichoke and cultivated cardoon [5-7]. The latter has been considered one of the most important perennial herbaceous cultivated plants mainly for the blanched leaf petioles, regarded in the Mediterranean area as a delicious speciality. Interest towards 
this crop is growing in European countries, especially in Spain, France, and Italy. In Portugal, Cynara cardunculus L. cardoon is traditionally used as a source of two aspartic proteinases, Cardosins $\mathrm{A}$ and $\mathrm{B}$, for milk clotting in the manufacturing of cheese [8].

Mass spectrometry- (MS-) based proteomics has been used extensively to explore the proteomes of various cells and organisms. MS technology is now being applied to protein identification as it offers high sensitivity and, when coupled with liquid chromatography, reduces sample complexity and increases high-throughput capability [9].

Recently, high-resolution tandem mass spectrometers have enhanced robustness of peptide identification [10] based on matches between the measured mass of the peptides resulting from the protein digestion with high specificity proteases and the corresponding fragments in the protein databases. This approach is unable, however, to deal with proteomes or genomes that have not yet been sequenced.

In such cases, de novo sequence determination and sequence similarity searches provide alternative approaches to address the protein identification. Several software tools have been developed to deduce an amino acid sequence from an MS/MS spectrum [11, 12]. Furthermore, database search algorithms like BLAST $[13,14]$, recently optimised to deal with the sequence query length typical of mass spectrometric data $[15,16]$, have been utilized in cross-species identification of unknown proteins. However, the quality of tandem MS data and both de novo sequence interpretation and similarity search algorithms is critical, possibly leading to false positive or false negative matches. Such approaches have been successfully applied to protein identification from various organisms with unsequenced genomes [17, 18], including that of vegetables [19-22]. However, no rule has been established indicating the length, the number of fragmented peptides, or the de novo sequencing accuracy for a positive identification of homologous proteins. Moreover, the sequence percentage required for the identification of homologous proteins is also undetermined. Simulation has suggested that more than $80 \%$ of mammalian proteins could be positively identified on the basis of similarity between orthologous proteins of different species [23]. Therefore, for a successful characterization of a proteome by mass spectrometry, availability of the relative genome may not be a prerequisite.

On the basis of this background, the main objective of this study was to investigate the changes of the proteins of Cynara cardunculus L. var. in relation to the etiolation process. Therefore, we compared global protein expression profiles of green and etiolated fleshy stalks of cultivated cardoon.

\section{Materials and Methods}

2.1. Plant Materials. Green and etiolated fleshy stalks of cultivated cardoon (Cynara cardunculus L. var. altilis DC) were used for this study. The system was realized in the Agricultural Company situated near to San Nicola Manfredi in Benevento district (Campania region) in March with direct dwell seeds in distant rows with $80 \mathrm{~cm}$ between each plant in plots of $3 \times 3$ meters. They have placed three seeds per hole, which leads to a single plant. In the period of May-June, the plants were in the rosette phase. The plants reached their complete development at the end of summerbeginning of autumn (August-September). At the end of autumn (October), some green fleshly stalks were collected from three adjacent plants, quickly washed in sterile distilled water, freeze-dried, and stored at $-80^{\circ} \mathrm{C}$ until analysis. Continuous dark for 25/30 days provoked plant etiolation as the leaves became more tender, white, and sweet as well. At the end of December, the etiolated fleshly stalks were collected and quickly washed in sterile distilled water, freezedried, and stored at $-80^{\circ} \mathrm{C}$ until analysis.

2.2. Protein Extraction. Total proteins were extracted by a phenol-based method described by Saravanan and Rose [24]. The fleshy stalks were finely powdered in liquid nitrogen, using a mortar, and suspended in $7.5 \mathrm{~mL}$ of extraction buffer $(700 \mathrm{mM}$ sucrose, $500 \mathrm{mM}$ Tris- $\mathrm{HCl}, \mathrm{pH}$ 8.0, $50 \mathrm{mM}$ EDTA, $100 \mathrm{mM} \mathrm{KCl}, 2 \% \mathrm{v} / \mathrm{v} \beta$-mercaptoethanol, and $1 \mathrm{mM}$ phenylmethylsulphonylfluoride), by vortexing for 15 minutes at $4^{\circ} \mathrm{C}$. After addition of an equal volume of phenol saturated $500 \mathrm{mM}$ Tris- $\mathrm{HCl}$, $\mathrm{pH} 7.5$, the mixture was vortexed extensively for 10 minutes and then centrifuged at $10000 \mathrm{~g}$ for 15 minutes at $4^{\circ} \mathrm{C}$. The upper phenol phase was removed and extracted twice with the extraction buffer. Proteins were precipitated from the phenol phase by the addition of five volumes of saturated ammonium acetate in methanol, overnight at $-20^{\circ} \mathrm{C}$. Precipitated proteins were centrifuged at $10000 \mathrm{~g}$ for 30 minutes.

2.3. 2-DE. Protein pellets were washed with ice-cold methanol (once) and ice-cold acetone (three times) dried and solved in IEF buffer ( $9 \mathrm{M}$ urea, $4 \% \mathrm{w} / \mathrm{v}$ CHAPS, $20 \mathrm{mM}$ DTT and $1 \% \mathrm{w} / \mathrm{v}$ ampholyte pH 3-10) (Bio-Rad, Hercules, CA, USA). Protein concentration was quantified using the BioRad protein assay using BSA as a standard. IPG strips (18-cm pH 4-7 Bio-Rad ReadyStrip), rehydratated overnight with $315 \mu \mathrm{L}$ of IEF buffer containing $400 \mu \mathrm{g}$ of total proteins. Proteins were focussed using a Protean IEF Cell (Bio Rad) at $12^{\circ} \mathrm{C}$, applying $250 \mathrm{~V}(1 \mathrm{~h}), 1000 \mathrm{~V}(5 \mathrm{~h})$, and $8000 \mathrm{~V}$ for a total of $52 \mathrm{kVh}$. Prior to the second dimension, the gel strips were reduced with $2 \% \mathrm{w} / \mathrm{v}$ DTT in $6 \mathrm{M}$ urea, $30 \% \mathrm{w} / \mathrm{v}$ glycerol, $2 \% \mathrm{w} / \mathrm{v}$ SDS, $50 \mathrm{mM}$ Tris- $\mathrm{HCl} \mathrm{pH} 8.8$, containing $0.01 \% \mathrm{w} / \mathrm{v}$ bromophenol blue for 20 minutes, followed by 20 minutes in the same buffer containing $2.5 \% \mathrm{w} / \mathrm{v}$ iodoacetamide. Electrophoresis in the second dimension was carried out using a Protean apparatus (BioRad) and 12\% polyacrylamide gels $(18 \mathrm{~cm} \times 24 \mathrm{~cm} \times 1 \mathrm{mM})$ in $25 \mathrm{mM}$ Tris ( $\mathrm{pH} 8.3$ ), $1.92 \mathrm{M}$ glycine, and $1 \% \mathrm{w} / \mathrm{v}$ SDS, with $70 \mathrm{~V}$ $(135 \mathrm{~mA})$ being applied for $16 \mathrm{~h}$. Each sample was run in triplicate. Protein spots were annotated only if detectable in all gels [25].

2.4. Image Acquisition and Analysis. 2-DE gels were stained with colloidal Coomassie G250 and scanned using a GS800 calibrated densitometer (Bio-Rad). Image analysis was 
performed using the PDQuest software (Bio-Rad). Spot detection and matching between gels were performed automatically, followed by manual verification. After normalization of the spot densities against the whole-gel densities, the percentage volume of each spot was averaged for six different (three replicates of two samples) gels and the Student's $t$-test analysis $(P<.01)$ was performed to find out statistically significant protein fold changes associated to etiolation. A twofold change in normalized spot densities was considered indicative of a differentially expressed component.

2.5. In-Gel Tryptic Digestion. Spots in the Coomassie Brilliant Blue G-250-stained 2-DE gel were excised manually and before being subjected to in-gel trypsinolysis as previously reported by Mamone et al. [26], reduced (10 mM DTT in $100 \mathrm{mM} \mathrm{NH} \mathrm{NHCO}_{3}$ allowing to react for $45 \mathrm{~min}$, at $55^{\circ} \mathrm{C}$ ) and alkylated with $55 \mathrm{mM}$ iodoacetamide in $100 \mathrm{mM}$ $\mathrm{NH}_{4} \mathrm{HCO}_{3}$ for $30 \mathrm{~min}$ at $25^{\circ} \mathrm{C}$, in the dark. The resulting tryptic digest was dissolved in $40 \mu \mathrm{L}$ of acetonitrile and $5 \%$ formic acid solution $(1: 1 \mathrm{v} / \mathrm{v})$ and then the sample concentrated with vacuum centrifuge on medium heat to one-tenth initial volume for mass spectrometric analysis.

2.6. Reverse Phase Capillary Chromatography. Reverse phase capillary chromatography coupled with quadrupole time-offlight tandem mass spectrometry was carried out using a Waters CapLC ternary pump system connected through a stream-select valve module to the nano-Z-spray source of the mass spectrometer. The sample was injected into the system through the CapLC autosampler. Solvent A and C consisted of water with $0.1 \%$ TFA, and solvent B consisted of acetonitrile with $0.1 \%$ TFA.

The protein digest was preconcentrated and desalted on a precolumn cartridge packed with Atlantis dC18 resin at flow rate of $20 \mu \mathrm{L} / \mathrm{min}-1$ over 3 minutes. After switching to pumps $\mathrm{A}$ and $\mathrm{B}$, a linear gradient from 5 to $70 \%$ of $\mathrm{B}$ over $45 \mathrm{~min}$ at a flow-rate of $300 \mathrm{~nL}$ min-1 $(2 \% \mathrm{~B} / \mathrm{min})$ was applied to the precolumn cartridge and then used to elute the sample from the Atlantis dC18 resin analytical column $(15 \mathrm{~cm} \times 75 \mu \mathrm{m}$ i.d.).

2.7. Mass Spectrometry. All mass spectra were acquired using a quadrupole-TOF hybrid mass spectrometer Waters QTOF II equipped with a nano-Z-spray source operating in positive ion mode. The ionization conditions used included a capillary voltage of $2.6 \mathrm{kV}$, source temperature of $80^{\circ} \mathrm{C}$, and no nebulising gas. External calibration was applied to all data using Glu1-Fibrinopeptide B (Sigma-Aldrich) MS/MS fragments over a mass range from 50 to $1600 \mathrm{~m} / \mathrm{z}$.

Survey scan acquisition was done on-line with capillary chromatographic separation; an initial TOF-MS scan was acquired over the mass range of $400-1600 \mathrm{~m} / \mathrm{z}$ each second, with switching criteria for MS to MS/MS that included ion intensity (10 counts/s) and charge state $(+2$ to +4$)$. MS/MS of precursor ion selected was acquired over the mass range of $50-1600 \mathrm{~m} / \mathrm{z}$. The collision energy used varied automatically according to the mass and charge state of the eluting peptides.

2.8. Nanoflow LC-ESI-MSMS. LC-ESI-MSMS analysis was performed using a Q-TOF Ultima mass spectrometer (Waters/Micromass UK Ltd., Manchester, UK) utilizing automated data-dependent acquisition. A nanoflow HPLC system (Waters CapLC (Waters/Micromass UK Ltd., Manchester, UK) was used for chromatographic separation of the peptide mixtures prior to MS detection. The peptides were concentrated and desalted on a precolumn cartridge packed with Atlantis dC18 resin (Waters CapLC, Waters/Micromass UK Ltd., Manchester, UK) and eluted at $200 \mathrm{~nL} / \mathrm{min}$ by an increasing concentration of acetonitrile $(2 \% / \mathrm{min}$ gradient) onto an analytical column $(15 \mathrm{~cm} \times 75 \mu \mathrm{m}$ i.d. $)$ also packed with Atlantis dC18 resin. An MS-TOF survey spectrum was recorded for $1 \mathrm{~s}$. The five most abundant ions present in the survey spectrum were automatically mass-selected and fragmented by collision-induced dissociation ( $4 \mathrm{~s}$ per MSMS spectrum). The MSMS data were converted to a pkl file format using the Mass-Lynx 3.5 ProteinLynx software, and the resulting pkl file was searched against the NCBInr protein sequence databases using the Waters ProteinLynx GlobalSERVER v2.2.5 (PLGS).

2.9. Protein Identification. Acquired raw data were deisotoped and converted to pkl files using Waters ProteinLynx GlobalSERVER v2.2.5 (PLGS). Database search was performed against the tryptic peptides of entire taxonomy order Viridiplantae of NCBI database using a peptide tolerance of $0.1 \mathrm{Da}$ and fragment mass tolerance of $0.2 \mathrm{Da}$, allowing a maximum number of two missed cleavages. Carbamidomethylated cysteine was set as fixed modification, while oxidized methionine was set as variable modification. Automod algorithm was used to determine additional posttranslational modifications and/or single amino acid substitution. The MS/MS spectra of peptides not identified by the previous two algorithms were submitted to the PLGS "de novo" sequence algorithm and the sequences obtained were BLAST searched against of NCBI Viridiplantae database using the same software tool. Alignments parameters were adjusted to search for a short input sequence, that is, PAM30MS matrix and expected threshold set to 1000. Redundant database search and de novo sequence alignments match several homologous proteins of different species, making difficult to establish a scoring system at protein level. Data were filtered at peptide level allowing only peptide having at least three consecutive b- or $\mathrm{y}$-fragment ions of an homologous protein sequence tag and a ladder score (percentage of $\mathrm{y}$ - and b-ions detected) greater than 40. Using a decoy database, generated randomising NCBI Viridiplantae database, the calculated false positive discovery rate was limited to $6.7 \%$.

To detect the potential conserved domains included in the sequences deduced by mass spectrometry [27], the peptide sequences inferred were blast searched using the protein BLAST tools limiting the results to the accession numbers of homologous proteins having the higher number 
of matches in each spot. Blast algorithm used was blastp with BLOSUM62 matrix and expected value set to 10.

\section{Results and Discussion}

3.1. Proteome Changes Observed during Etiolation. Proteins extracted from green and etiolated fleshy stalks of cultivated cardoon were separated by $2 \mathrm{D}$-PAGE and spots were visualized by $\mathrm{CBB}$ staining. Analysis of spots on the $2-\mathrm{DE}$ gel using the PDQuest 2D image analysis software (BioRad) indicated approximately 200 proteins having an $M_{r}$ less than $100 \mathrm{kDa}$ and a $p I$ in the range $4-7$ (Figure 1). Taking into account the spot areas and their intensity, 60 protein spots were selected along each 2 -DE gel for green and etiolated fleshy stalks. 21 out of 60 proteins were differentially expressed in green and etiolated fleshy stalks $(P<.01)$ while 23 protein spots were found to be common to two types of fleshy stalks. By capillary LC-nano-ESI Q-TOF MS/MS sequence analysis 46 proteins (82\%) were successfully identified. Among the sequences inferred from Cynara cardunculus proteins identified within 60 electrophoretic spots, $\sim 71 \%$ tryptic peptides exactly matched the molecular mass and sequence of orthologous peptides occurring in the Viridiplantae database, the remaining differed by one or more amino acid residues inferred by the de novo sequence. The identification of conserved domains along the protein stretches using sequence similarity searches provides additional confidence on the function of the identified proteins although additional experiments are necessary to obtain ultimate confirmation. Occurrence of false positive and false negative matches may affect identification even using robust high-resolution techniques. Error may be caused essentially by sequencing errors derived from incomplete fragmentation and/or interpretation of spectra and/or erroneous sequence alignment. Taking into account these limitations, sequence similarity searches based on capillary LC coupled with nanoESI Q-TOF data seem to represent a valid analytical tool capable of extending proteomic analysis to unsequenced genome organisms. As expected, Ile and Leu residues were indistinguishable in low-energy collision-induced dissociation spectra. Similarly, neither Gln nor Lys differing in 0.036 Da was discriminated, except for the C-terminal Lys in tryptic peptides.

The relative quantitative variations of the identified protein are shown in Table 1. Among the identified upregulated proteins, a large portion of the spots is represented by proteins involved in carbon/energy metabolism, defense from environmental/pathogen stresses, and oxidative stress control.

3.2. Proteins Associated with Carbon and Energy Metabolism. Different key enzymes of glycolysis related to starch catabolism are upregulated during etiolation. Their abundance likely reflected the pivotal role of this pathway that fuels substrates for respiration and organic acid and pigment synthesis from imported sugars during etiolation, as shown by cytosolic malate dehydrogenase (spot 16) that are implicated in the glycolyis and gluconeogenesis. Interestingly,

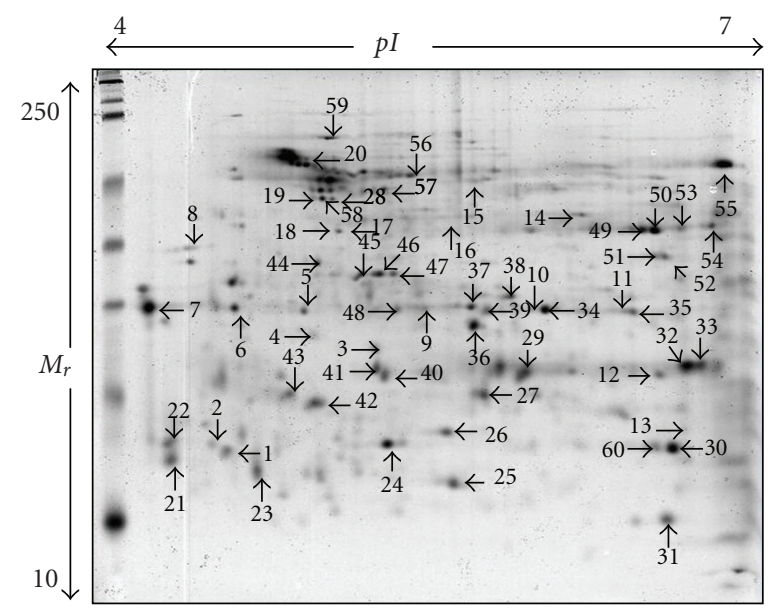

(a)

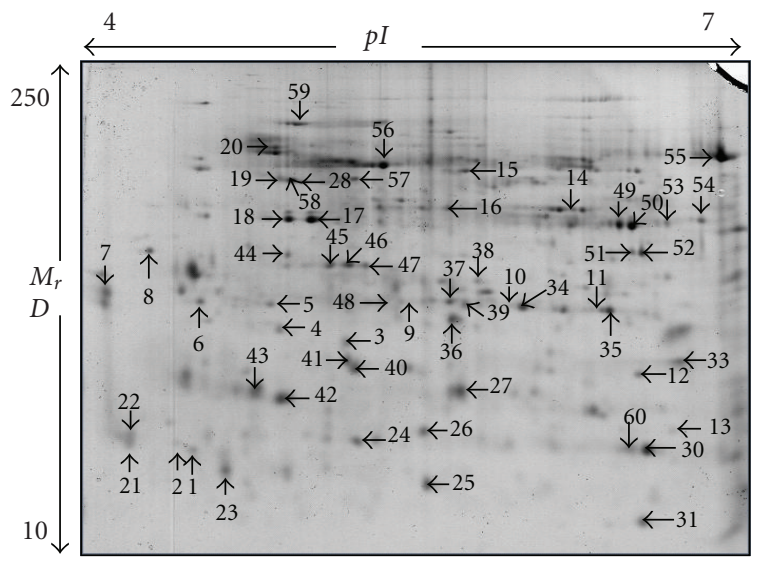

(b)

FIGURE 1: Representative 2-DE gels of total protein extracts from fleshy stalks of cultivated cardoon (Cynara cardunculus L. var. altilis DC). (a) Etiolated fleshy stalks; (b) green fleshy stalks. The horizontal bar indicates $p I$ and the vertical one $M_{r}$. Spot numbering refers to Table 1. Gels were stained with colloidal CBB G-250.

levels of glycolytic enzymes on the whole decreased in etiolated fleshy stalks of cultivated cardoon (spot 10). In fact triosephosphate isomerase catalyses the reversible interconversion of the triose phosphate isomers dihydroxyacetone phosphate and D-glyceraldehyde 3-phosphate. It plays an important role in glycolysis and it is essential for efficient energy production. When the cytosolic triosephosphate accumulation inhibits the respiration, it triggers malate efflux from mitochondria and its oxidation. In fact, while starch is the predominant storage form in green fleshy stalks, etiolation is characterized by a decline in starch content, sucrose import, and accumulation of hexoses. Therefore, in photosynthetic tissues, mitochondria are obligatory partners of chloroplasts with respect to $\mathrm{CO}_{2}$ light-dependent assimilation, due to their implication in the photorespiration pathway.

Spot 21 was identified as Acyl-CoA-binding protein (ACBP), homologous to that from Panax ginseng, and is a 


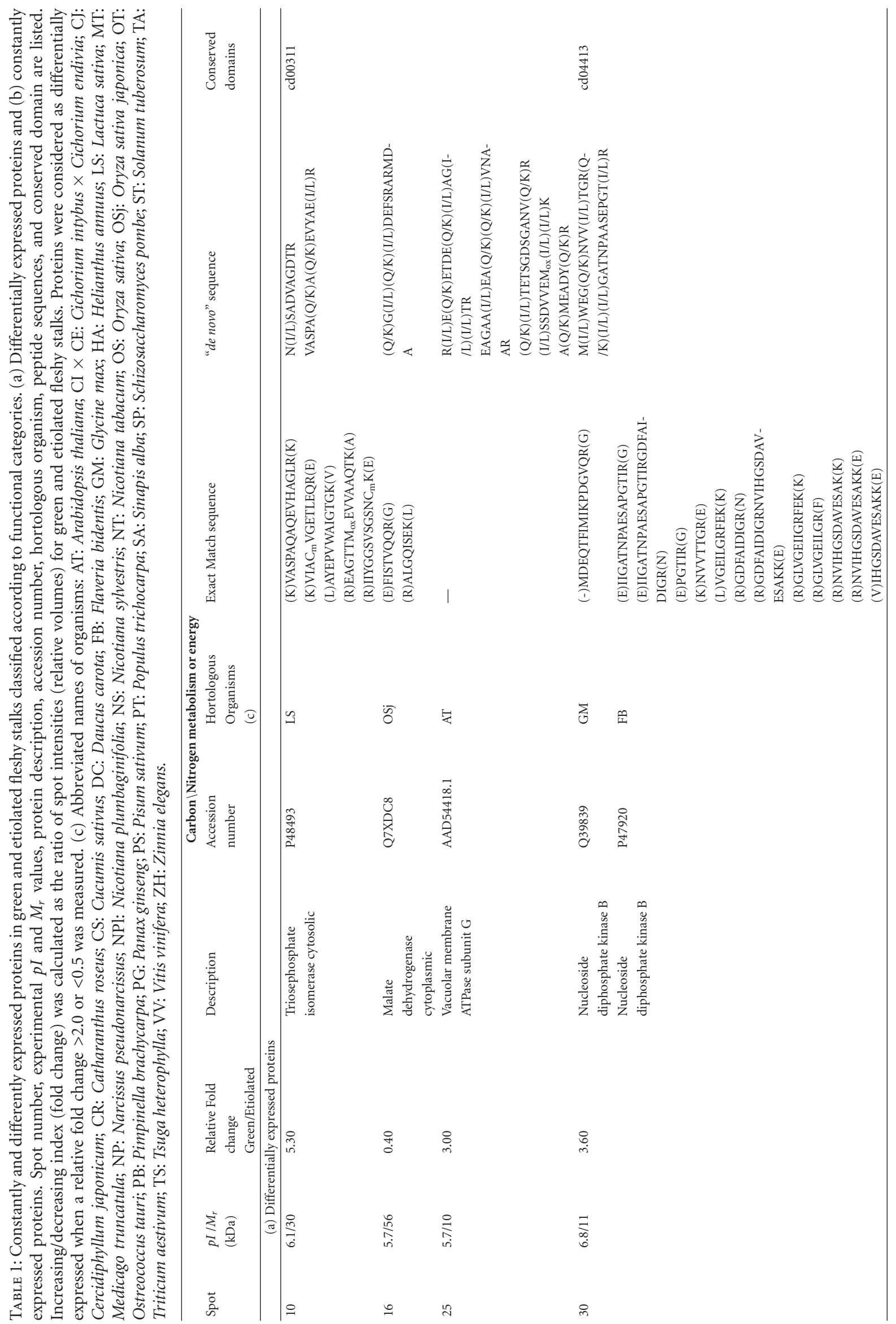




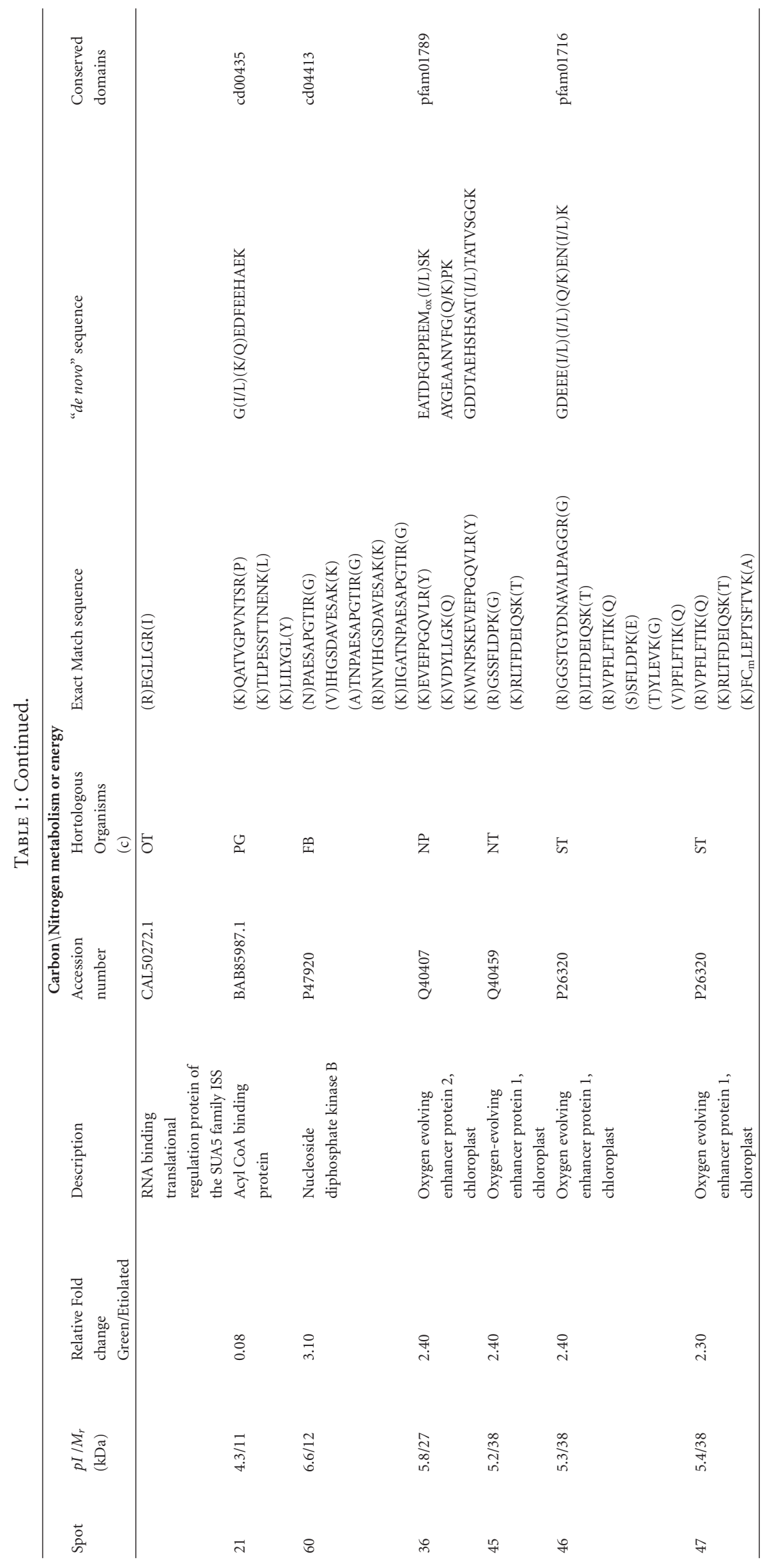




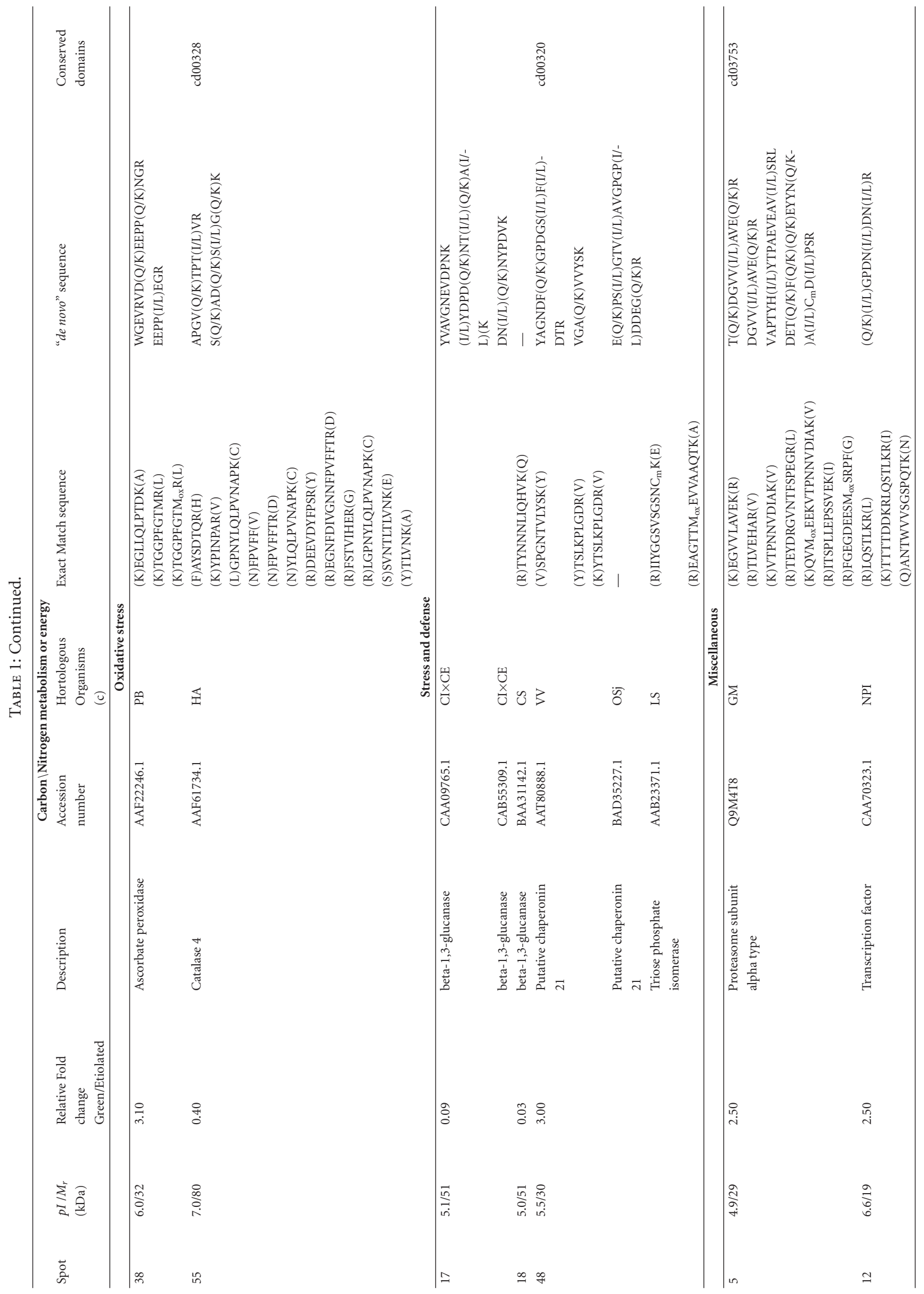




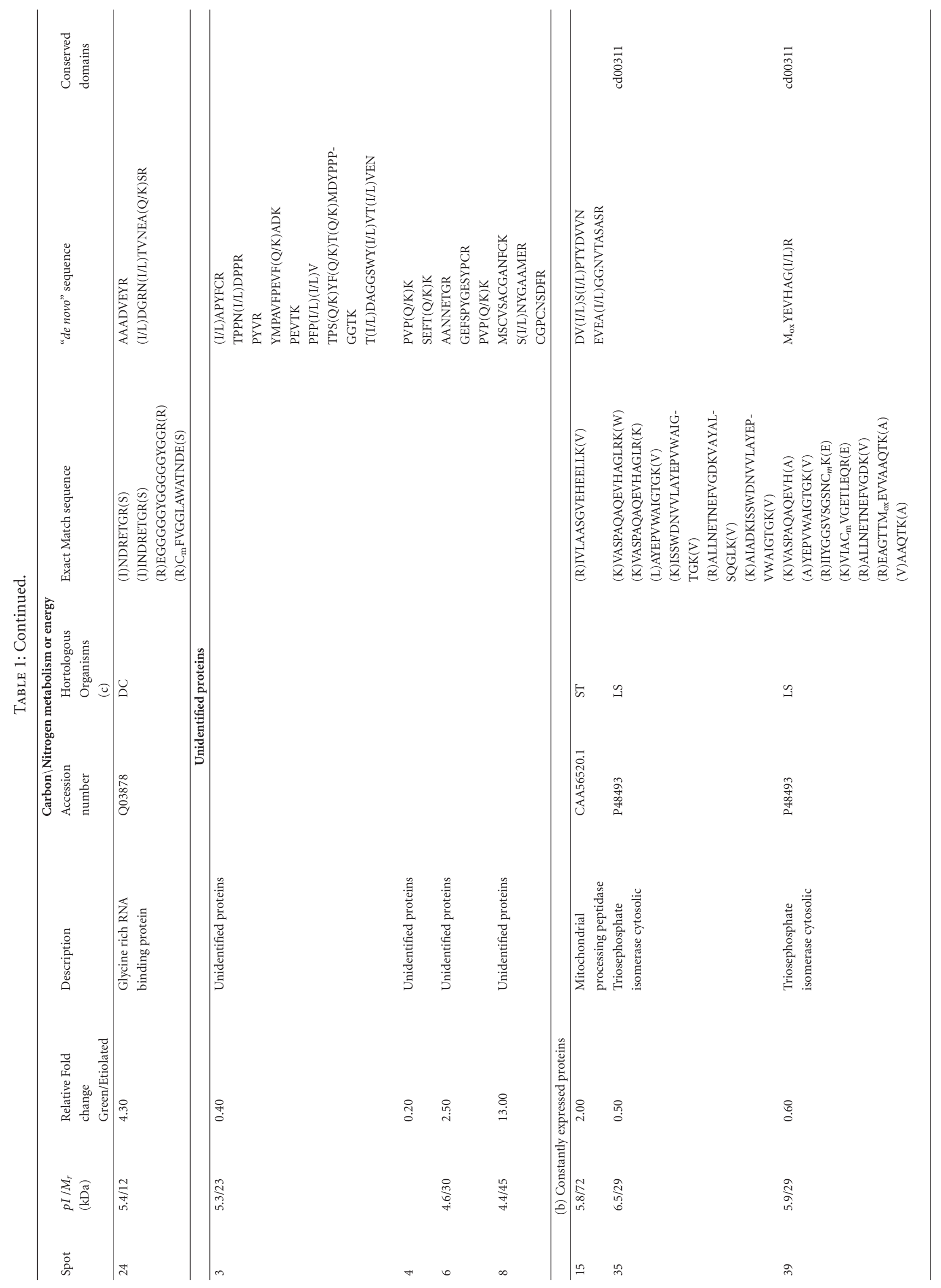




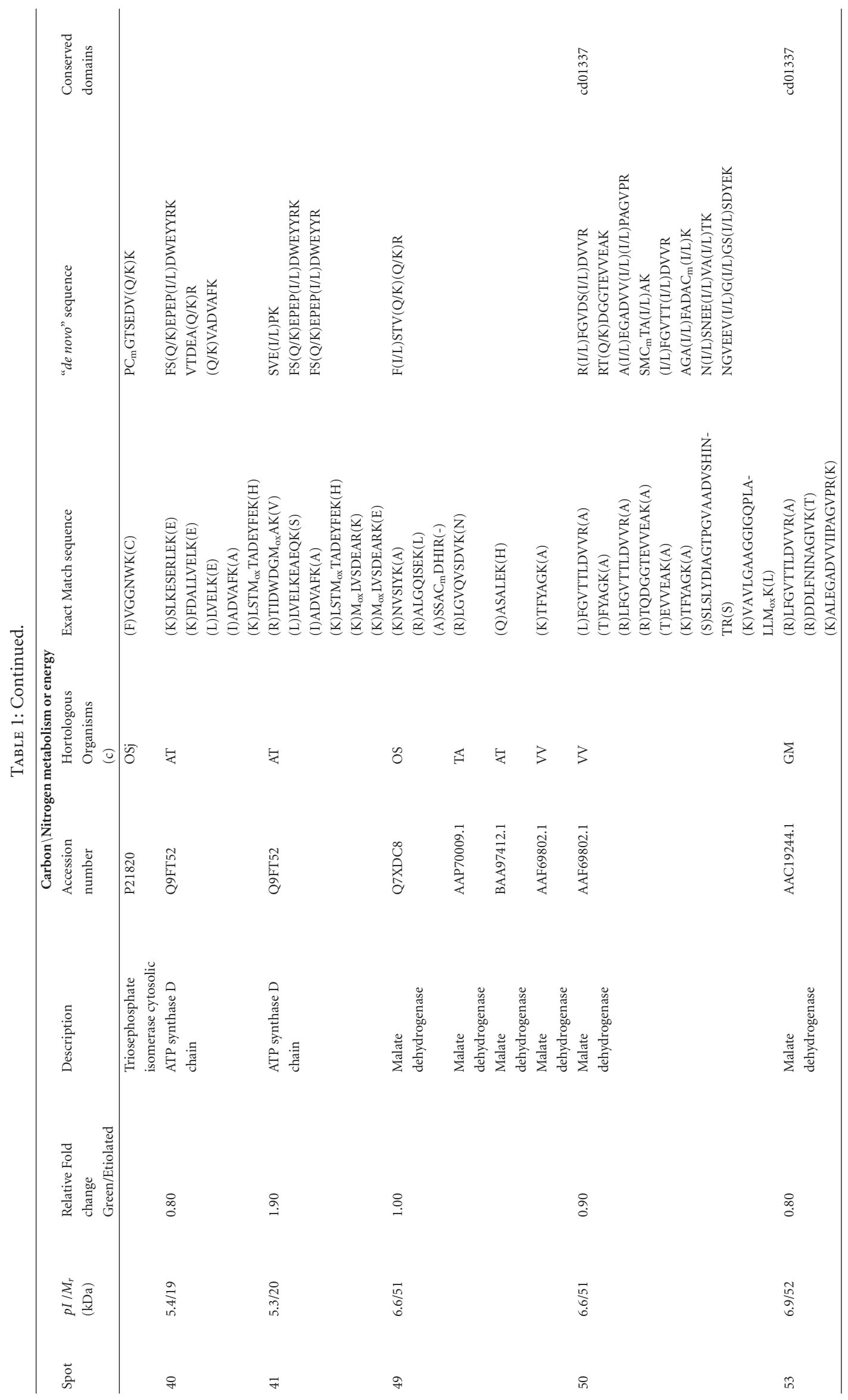




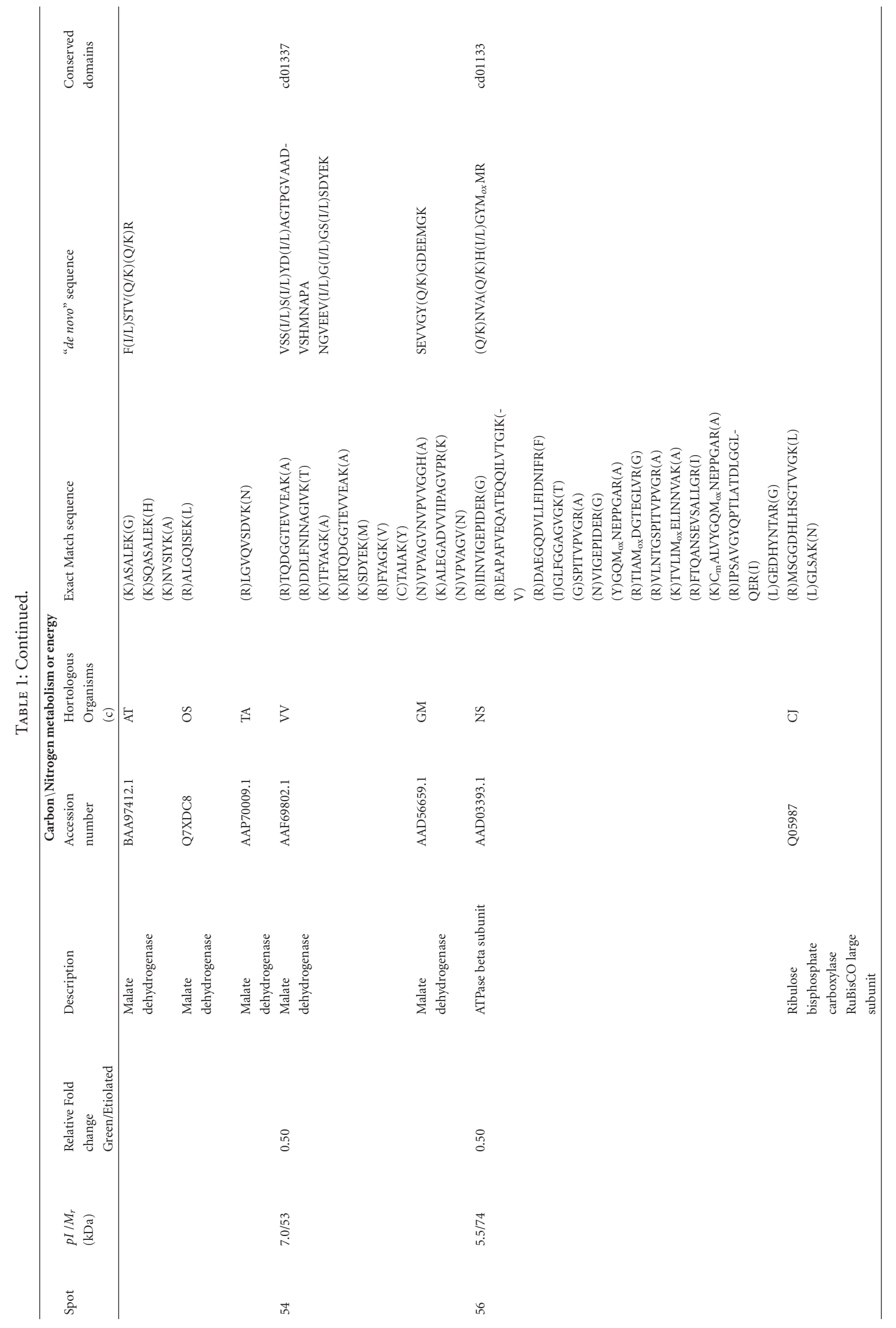




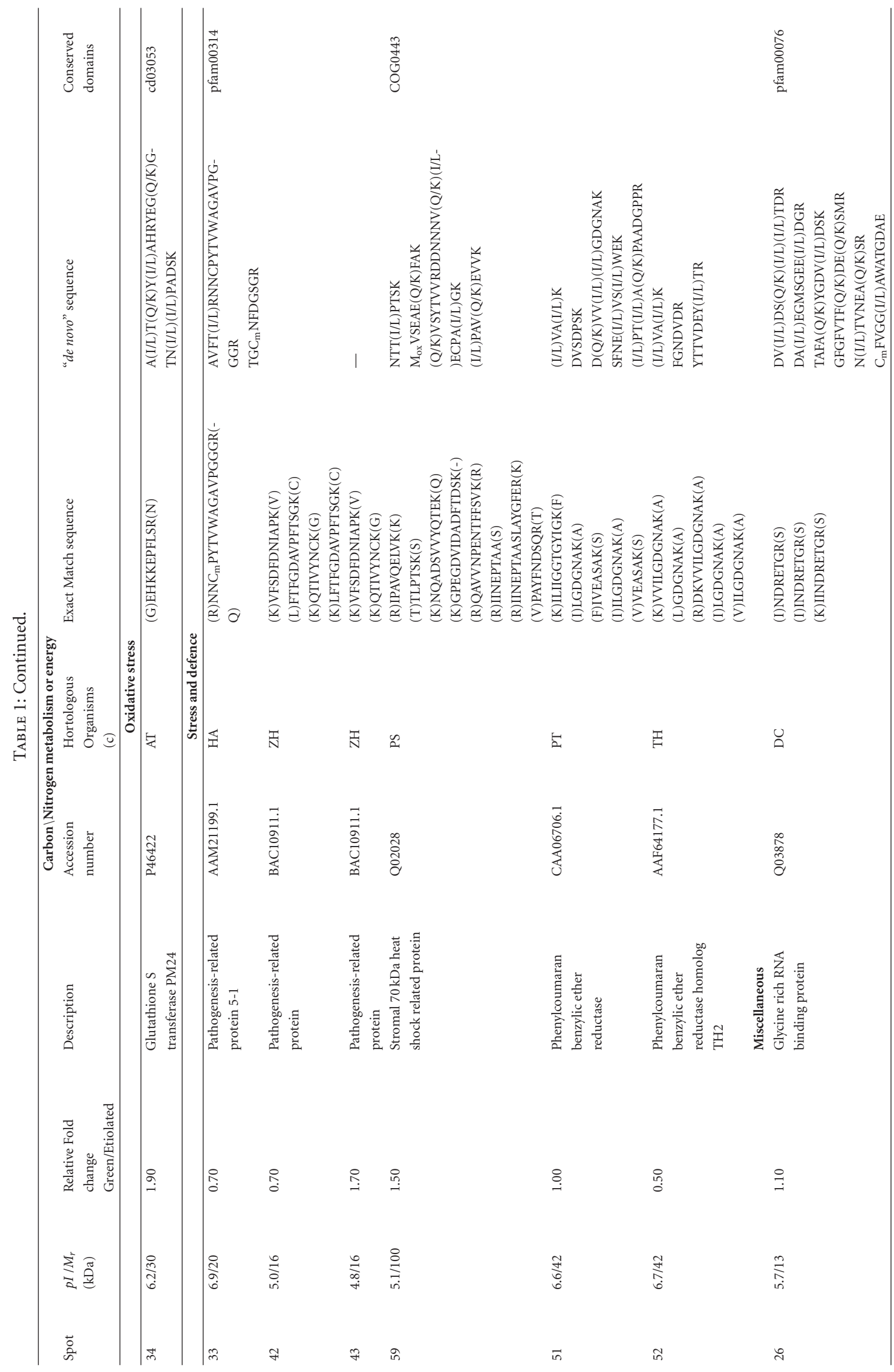




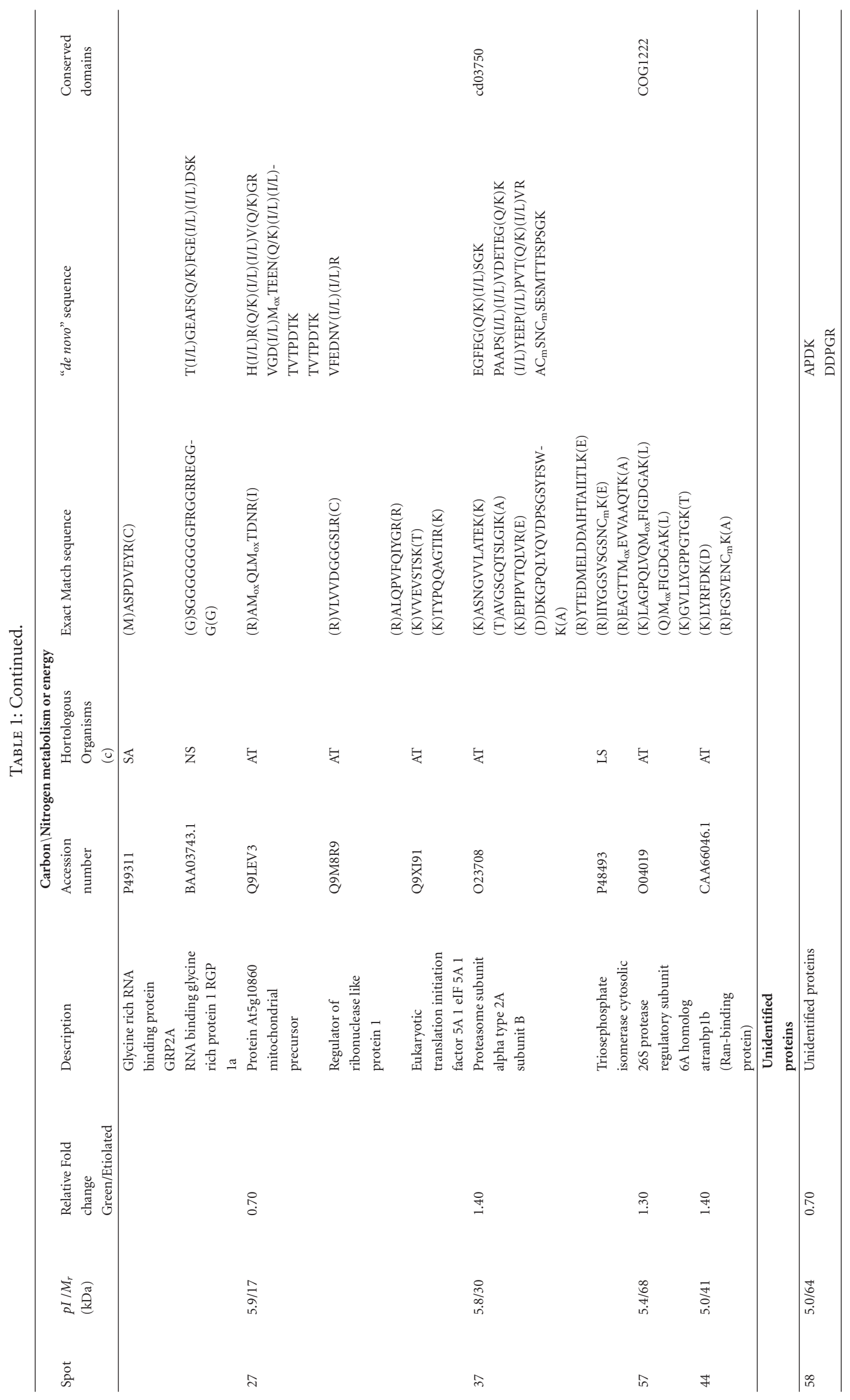


$10 \mathrm{kDa}$ protein that binds with high affinity to $\mathrm{C}_{12}-\mathrm{C}_{22}$ acylCoA esters. In vitro and in vivo experiments suggest that it is involved in multiple cellular tasks including modulation of fatty acid biosynthesis, enzyme regulation, regulation of the intracellular acyl-CoA pool size, donation of acylCoA esters for $\beta$-oxidation, vesicular trafficking, complex lipid synthesis, and gene regulation. In higher plants, de novo fatty acid biosynthesis occurs in the chloroplasts. Plastid-synthesized fatty acyl-CoAs, palmitoyl-CoA (16:0CoA), and oleoyl-CoA (18:1-CoA) are likely exported by intracellular lipid transporters to the endoplasmic reticulum (ER) for the "eukaryotic pathway" in lipid biosynthesis. The process as to how the fatty acyl-CoAs are exported from the chloroplasts to the ER remains unclear to date. The ACBP that was first reported in Arabidopsis was proposed to facilitate transport and maintenance of long-chain acylCoA esters in the cytosol. This assumption was based on a lack of knowledge at that time that five other ACBPs exist in Arabidopsis [28]. Recently studies suggest that those proteins are light-regulated [29]; in fact we observed an increased value of this protein in the etiolated flesh stalks.

Moreover, some enzymes involved in electron transport and energy production are downregulated. When exposed to dark, photosynthetically competent chloroplast developed into photosynthetically incompetent etioplast. This involved the destruction of component of the photosynthetic apparatus and prononouced alterations in plastid ultrastrutture that include the conversion of stromal and stacked thylakoid structures characteristic of chloroplast into distinctive prolamellar body. In this study, vacuolar ATP synthase (spot 25), the photosystem II oxygen-evolving complex protein 1 (spots $45,46,47)$, and photosystem II oxygen-evolving complex protein 2 (spot 36) were downregulated (Table 1). Infact, the oxygen evolving protein plays an important role in stabilizing, binding, and maintaining functional conformation of the manganese cluster which directly catalyzes the $\mathrm{H}_{2} \mathrm{O}$ splitting reaction [30]. After exposure to the dark the protein decreases significantly, indicating that the oxygen evolving complex of PSII was flourished by exposure to light.

3.3. Proteins Associated with Oxidative Stresses. Etiolation has been described as an oxidative process which might lead to the production or accumulation of a large amount of harmful active oxygen species (AOS) or, more specifically, of hydrogen peroxide as a by-product of increased electron transport activity in the mitochondria. The presence of damaging hydrogen peroxide might explain the strong presence of ascorbate peroxidase, with the function of contrasting toxic peroxide [31].

L-ascorbate peroxidase activity (spot 38) showed a remarkable decreasing value in etiolated as compared to green fleshy stalks. Ascorbate is a major metabolite in plants. It is an antioxidant and, in association with other components of the antioxidant system, protects plants against oxidative damage resulting from aerobic metabolism, photosynthesis, and a range of pollutants. In fact, the degradation of the photosynthetic apparatus reduces the presence of the L-ascorbate peroxidase.
Catalase (cd00328) (spot 55) was identified as a homologue of Heliantus annuus catalase 4 and was also upregulated in etiolated fleshy stalks. The increase in antioxidant enzymes was indicative of a pro-oxidant signal under a nonphotosynthetic condition. Besides, glutathione S-transferase (spot 34) was similar in green and etiolated fleshy stalks.

3.4. Proteins Associated with Stress and Defense. Proteins homologous to stromal $70 \mathrm{kDa}$ heat-shock protein (spot 59) were detected in both green and etiolated fleshy stalks. The chaperonin 21 (spot 48) was downregulated; it has been demonstrated that this protein has a more general role in plastid development and may influence the folding of numerous chloroplast protein such RuBisCO (EC 4.1.1.39) [32].

The beta 1,3 glucanase (spots 17,18 ) proteins are upregulated and are involved in the response to biotic stresses that are differentially expressed during etiolation.

Besides, phenylcoumaran benzylic ether reductase (PCBER) (spots 51, 52) was identified as protein constantly expressed, which plays a significant role in the biosynthesis of important plant defense phenylpropanoid-derived compounds, based on known catalytic function component presiding over defense mechanisms. These proteins possess NADPH binding sites and appear to be cytosolic enzymes, since they lack secretory pathway signal sequences. In addition, they may be regulated in a comparable manner, not only at the transcriptional level but also at the enzymatic level by protein phosphorylation, as evidenced by several potential phosphorylation sites that are conserved among all of the members [33].

Enzymatic assay with recombinant Bet v 6 and Pyr c 5 showed PCBER catalytic activity for both recombinant allergens [34]. Therefore, PCBER may represent a new class of cross-reactive allergens of birch pollen and plant food.

3.5. Miscellaneous. Information on several identified proteins that did not group in the above classes was very poor; in particular, their function was postulated on the basis of the homology sequence criteria. In only a few cases, important functions in some physiological processes have emerged for definite proteins. In this respect, it is worth noting that three proteins are involved in the control of programmed cell death (PCD), namely, the proteasome alpha subunit type $2 \mathrm{~A}$ (spot 37 ), 26S protease regulatory subunit $6 \mathrm{~A}$ (spot 57 ), and proteasome alpha subunit type 5 (spot 5) containing a ubiquitin-like domain interacting with catalytically active proteasomes [35]. Increasing evidence indicates that PCD plays a pivotal role in diverse plant processes, such as embryogenesis, senescence, or pathogen defense [36, 37], and we find out that the proteasome alpha subunit type 5 (spot 5) is downregulated and decreased its value in the etiolating process but data are lacking on its involvement in this process.

Ran-binding protein $1 \mathrm{~b}$, homologous to that from Arabidopsis (AtRanBP1b), was also identified (spot 44). Ranbinding proteins are activators of Ras-related nuclear small GTP-binding proteins (Ran) and in Arabidopsis have been 
TAble 2: Protein expressed exclusively in etiolated cultivated cardoon. Spot number, experimental $p I$ and $M_{r}$ values, protein description, accession number, hortologous organism, peptide sequences, and conserved domain are listed. (a) Abbreviated names of organisms: AT: Arabidopsis thaliana; GM: Glycine max; SS: Solenostemon scutellarioides.

\begin{tabular}{|c|c|c|c|c|c|c|c|}
\hline \multicolumn{8}{|c|}{ Miscellaneous } \\
\hline Spot & $\begin{array}{l}p I / M_{r} \\
(\mathrm{kDa})\end{array}$ & Description & $\begin{array}{c}\text { Accession } \\
\text { number }\end{array}$ & $\begin{array}{l}\text { Hortologous } \\
\text { Organism (a) }\end{array}$ & Exact Match Sequence & "de novo" Sequence & $\begin{array}{c}\text { Conserved } \\
\text { domains }\end{array}$ \\
\hline \multirow[t]{5}{*}{29} & $6.1 / 19$ & $\begin{array}{l}\text { CBS domain- } \\
\text { containing } \\
\text { protein }\end{array}$ & ABK64186.1 & SS & (K)LITVTPDTK(V) & AVVSEHREE(I/L)DR & \\
\hline & & & & & (R)AMQLMTDNR(I) & & \\
\hline & & & & & (K)VGDIMTEENKLITVTPDTK(V) & & \\
\hline & & $\begin{array}{l}\text { Eukaryotic } \\
\text { translation } \\
\text { initiation factor } \\
5 \mathrm{~A}\end{array}$ & Q9XI91 & AT & $(\mathrm{K}) \operatorname{VVEVSTSK}(\mathrm{T})$ & & \\
\hline & & & & & (K)TYPQQAGTIR(K) & & \\
\hline \multirow[t]{2}{*}{32} & $6.9 / 20$ & Protein $\mathrm{P} 21$ & P25096 & GM & (R)VVFCP(-) & & \\
\hline & & & & & (R)TGCNFDGSGR(G) & & \\
\hline
\end{tabular}

shown to be involved in the regulation of auxin-induced mitotic progression [38]. Another identified protein for which information is very scarce or missing was the glycinerich RNA-binding protein (spot 24) which decreases its value in the etiolation process. Besides, two proteins are exclusively expressed during etiolation (spots 29 and 32; Table 2) in the fleshy stalks.

Spot 29 is a cystathionine beta-synthase (CBS), domaincontaining protein also present in the proteome of archaeobacteria, prokaryotes, and eukaryotes, having divergent functions ranging from metabolic enzymes and transcriptional regulators to ion channels and transporters. Although the precise function has not yet been elucidated, CBS domains could have physiological importance because point mutations are responsible for several hereditary diseases in humans [39].

Protein P21 (P25096) (spot 32) is classified as a rasoncogene-encoded p 21 protein in humans and is known to cause large numbers of tumours. The protein differs from its healthy counterpart in eukaryotic cells in that it contains single amino acid substitutions at critical positions of the polypeptide chain, such as $\mathrm{Gly}^{12}, \mathrm{Gly}^{13}, \mathrm{Ala}^{59}$, and $\mathrm{Gln}^{61}[40]$. In a recent study [41], one quantitative trait locus (QTL), fw2.2, has been demonstrated as being responsible for the domestication of the tomato. When transformed into largefruited cultivars, a cosmid derived from the fw2.2 region of a small-fruited wild species reduced fruit size by the predicted amount and had the gene action expected for fw2.2. The cause of the QTL effect is a single gene, ORFX, expressed early in the floral development. It controls carpel cell number and its sequence has structural features similar to that of human oncogene c-H-ras p21

\section{Concluding Remarks}

The 634,985 proteins of the Viridiplantae database, including the complete genome of Arabidopsis thaliana and other important plants, have allowed identification of protein expression profiles of Cynara cardunculus under usual light or dark conditions.

In this study, constitutive and differentially expressed proteins in green and etiolated fleshy stalks of cultivated cardoon (Cynara cardunculus L. var. altilis DC) have been discussed in relation to the plant etiolation process. In fact, the proteomic study indicated that, during etiolation, the differentially expressed proteins were involved mainly in starch metabolism and stress response. The major group in response to dark exposure was found to be proteins related to PSII complex. Thus groups comprised four proteins (spots $36 ; 45 ; 46 ; 47$ ) encoded by two nuclear genes (PSBO; PSBP). The decreasing values of these proteins explain the role that the PSII complex plays in the early photosynthetic phase. In fact its downregulation during the etiolating process is correlated to a progressive loose of function such as the oxidation of water to molecular oxygen. Therefore, the rapid decrease in the relative amount of these proteins following dark exposure suggests that the PSII complex is the lightdriven water: plastoquinone oxidoreductase.

In conclusion, this study allowed to identify the proteins that are implicated in different physiological and defence process besides their involvement in the response to stress, as the etiolation process. This one is to be considered as a reaction that helps plants to survive in the dark condition, contributing to the response at the physiological effects due to this exposure. 


\section{References}

[1] D. Bois, "Phanérogames légumières," in Les Plantes Alimentaires Chez Tous les Peuples et à Travers les Ages, vol. 1, pp. 5557, Paul Lechevallier, Paris, Farnce, 1927.

[2] J. Y. Péron, "L'élargissement de la gamme des espèces Légumières," in Journées D'étude et D'Information sur la Diversification des Cultures et des Produits dans la Filière Légumes, 1986, Angers 28 and 29 October (Abstract).

[3] J. Y. Péron, "Contribution à la réémergence de légumes oubliés," in Actes du Symposium la Diversité des Plantes, Légumières, Hier, Aujourd'hui ed Demain, pp. 135-152, 1986, AICPC/ACFEV/BRG.

[4] J. Y. Péron, "Seakale: a new vegetable produced as etiolated sprouts," in Advances in New Crops, J. Janick and J. E. Simon, Eds., pp. 419-422, Timber Press, Portland, Ore, USA, 1990.

[5] C. Foury, "Ressources génétiques et diversification de l'artichaut (Cynara scolymus L.)," Acta Horticulturae, vol. 242, pp. 155-166, 1989.

[6] A. Rottenberg and D. Zohary, "The wild ancestry of the cultivated artichoke," Genetic Resources and Crop Evolution, vol. 43, no. 1, pp. 53-58, 1996.

[7] S. A. Raccuia, A. Mainolfi, G. Mandolino, and M. G. Melilli, "Genetic diversity in Cynara cardunculus revealed by AFLP markers: comparison between cultivars and wild types from Sicily," Plant Breeding, vol. 123, no. 3, pp. 280-284, 2004.

[8] P. Veríssimo, C. Faro, A. J. G. Moir, Y. Lin, J. Tang, and E. Pires, "Purification, characterization and partial amino acid sequencing of two new aspartic proteinases from fresh flowers of Cynara cardunculus L," European Journal of Biochemistry, vol. 235, no. 3, pp. 762-768, 1996.

[9] L. M. F. de Godoy, J. V. Olsen, G. A. de Souza, G. Li, P. Mortensen, and M. Mann, "Status of complete proteome analysis by mass spectrometry: SILAC labeled yeast as a model system," Genome Biology, vol. 7, article R50, 2006.

[10] A. M. Frank, M. M. Savitski, M. L. Nielsen, R. A. Zubarev, and P. A. Pevzner, "De novo peptide sequencing and identification with precision mass spectrometry," Journal of Proteome Research, vol. 6, no. 1, pp. 114-123, 2007.

[11] J. A. Taylor and R. S. Johnson, "Sequence database searches via de novo peptide sequencing by tandem mass spectrometry," Rapid Communications in Mass Spectrometry, vol. 11, no. 9, pp. 1067-1075, 1997.

[12] A. Frank and P. Pevzner, "PepNovo: de novo peptide sequencing via probabilistic network modeling," Analytical Chemistry, vol. 77, no. 4, pp. 964-973, 2005.

[13] S. F. Altschul, T. L. Madden, A. A. Schäffer et al., "Gapped BLAST and PSI-BLAST: a new generation of protein database search programs," Nucleic Acids Research, vol. 25, no. 17, pp. 3389-3402, 1997.

[14] W. R. Pearson and D. J. Lipman, "Improved tools for biological sequence comparison," Proceedings of the National Academy of Sciences of the United States of America, vol. 85, no. 8, pp. 24442448, 1988.

[15] A. Shevchenko, S. Sunyaev, A. Loboda et al., "Charting the proteomes of organisms with unsequenced genomes by MALDI-quadrupole time-of-flight mass spectrometry and BLAST homology searching," Analytical Chemistry, vol. 73, no. 9, pp. 1917-1926, 2001.

[16] A. J. Mackey, T. A. Haystead, and W. R. Pearson, "Getting more from less: algorithms for rapid protein identification with multiple short peptide sequences," Molecular \& Cellular Proteomics, vol. 1, no. 2, pp. 139-147, 2002.
[17] L. Huang, R. J. Jacob, S. C.-H. Pegg et al., "Functional assignment of the $20 \mathrm{~S}$ proteasome from trypanosoma brucei using mass spectrometry and new bioinformatics approaches," Journal of Biological Chemistry, vol. 276, no. 30, pp. 2832728339, 2001.

[18] S. Lilla, R. Pereira, S. Hyslop, J. L. Donato, B. F. Le Bonniec, and G. de Nucci, "Purification and initial characterization of a novel protein with factor Xa activity from Lonomia obliqua caterpillar spicules," Journal of Mass Spectrometry, vol. 40, no. 3, pp. 405-412, 2005.

[19] H.-J. Kim, D.-Y. Lee, D.-H. Lee et al., "Strategic proteome analysis of Candida magnoliae with an unsequenced genome," Proteomics, vol. 4, no. 11, pp. 3588-3599, 2004.

[20] B. Granvogl, V. Reisinger, and L. A. Eichacker, "Mapping the proteome of thylakoid membranes by de novo sequencing of intermembrane peptide domains," Proteomics, vol. 6, no. 12, pp. 3681-3695, 2006.

[21] O. Østergaard, C. Finnie, S. Laugesen, P. Roepstorff, and B. Svensson, "Proteome analysis of barley seeds: identification of major proteins from two-dimensional gels ( $\mathrm{p} / 4-7$ ), Proteomics, vol. 4, no. 8, pp. 2437-2447, 2004.

[22] B. Samyn, K. Sergeant, S. Carpentier et al., "Functional proteome analysis of the banana plant (Musa spp.) using de novo sequence analysis of derivatized peptides," Journal of Proteome Research, vol. 6, no. 1, pp. 70-80, 2007.

[23] B. Habermann, J. Oegema, S. Sunyaev, and A. Shevchenko, "The power and the limitations of cross-species protein identification by mass spectrometry-driven sequence similarity searches," Molecular and Cellular Proteomics, vol. 3, no. 3, pp. 238-249, 2004.

[24] R. S. Saravanan and J. K. C. Rose, "A critical evaluation of sample extraction techniques for enhanced proteomic analysis of recalcitrant plant tissues," Proteomics, vol. 4, no. 9, pp. 25222532, 2004.

[25] C. Guarino, S. Arena, L. De Simone et al., "Proteomic analysis of the major soluble components in Annurca apple flesh," Molecular Nutrition and Food Research, vol. 51, no. 2, pp. 255262, 2007.

[26] G. Mamone, S. Caira, G. Garro et al., "Casein phosphoproteome: identification of phosphoproteins by combined mass spectrometry and two-dimensional gel electrophoresis," Electrophoresis, vol. 24, no. 16, pp. 2824-2837, 2003.

[27] A. Marchler-Bauer, J. B. Anderson, M. K. Derbyshire et al., "CDD: a conserved domain database for interactive domain family analysis," Nucleic Acids Research, vol. 35, no. 1, pp. 237240, 2007.

[28] N. J. Engeseth, R. S. Pacovsky, T. Newman, and J. B. Ohlrogge, "Characterization of an acyl-CoA-binding protein from Arabidopsis thaliana," Archives of Biochemistry and Biophysics, vol. 331, no. 1, pp. 55-62, 1996.

[29] S. Xiao, Q.-F. Chen, and M.-L. Chye, "Expression of ACBP4 and ACBP5 proteins is modulated by light in Arabidopsis," Plant Signaling \& Behavior, vol. 4, no. 11, pp. 1063-1065, 2009.

[30] A. Seidler, "The extrinsic polypeptides of photosystem II," Biochimica et Biophysica Acta, vol. 1277, no. 1-2, pp. 35-60, 1996.

[31] T. K. Prasad, "Mechanisms of chilling-induced oxidative stress injury and tolerance in developing maize seedlings: changes in antioxidant system, oxidation of proteins and lipids, and protease activities," Plant Journal, vol. 10, no. 6, pp. 10171026, 1996.

[32] F. Baneyx, U. Bertsch, C.E. Kalbach, S. M. van der Vies, J. Soll, and A. A. Gatenby, "Spinach chloroplast cpn21 co-chaperonin 
possesses two functional domains fused together in a toroidal structure and exhibits nucleotide-dependent binding to plastid chaperonin 60," Journal of Biological Chemistry, vol. 270, no. 18, pp. 10695-10702, 1995.

[33] D. R. Gang, H. Kasahara, Z.-Q. Xia et al., "Evolution of plant defense mechanisms: relationships of phenylcoumaran benzylic ether reductases to pinoresinol-lariciresinol and isoflavone reductases," Journal of Biological Chemistry, vol. 274, no. 11, pp. 7516-7527, 1999.

[34] F. Karamloo, S. Scheurer, A. Wangorsch, S. May, D. Haustein, and S. Vieths, "Pyr c 1, the major allergen from pear (Pyrus communis), is a new member of the Bet $\mathrm{v} 1$ allergen family," Journal of Chromatography. B, Biomedical Sciences and Applications, vol. 756, pp. 281-293, 2001.

[35] M. Kim, J.-W. Ahn, U.-H. Jin, D. Choi, K.-H. Paek, and H.S. Pai, "Activation of the programmed cell death pathway by inhibition of proteasome function in plants," Journal of Biological Chemistry, vol. 278, no. 21, pp. 19406-19415, 2003.

[36] D. L. Vaux and S. J. Korsmeyer, "Cell death in development," Cell, vol. 96, no. 2, pp. 245-254, 1999.

[37] E. Lam, N. Kato, and M. Lawton, "Programmed cell death, mitochondria and the plant hypersensitive response," Nature, vol. 411, no. 6839, pp. 848-853, 2001.

[38] S.-H. Kim and S. J. Roux, "An Arabidopsis Ran-binding protein, AtRanBP1c, is a co-activator of Ran GTPase-activating protein and requires the $\mathrm{C}$-terminus for its cytoplasmic localization," Planta, vol. 216, no. 6, pp. 1047-1052, 2003.

[39] S. Ignoul and J. Eggermont, "CBS domains: structure, function, and pathology in human proteins," American Journal of Physiology, vol. 289, no. 6, pp. C1369-C1378, 2005.

[40] M. R. Pincus, D. Chung, D. C. Dykes et al., "Pathways for activation of the ras-oncogene-encoded p21 protein," Annals of Clinical and Laboratory Science, vol. 22, no. 5, pp. 323-342, 1992.

[41] A. Frary, T. C. Nesbitt, S. Grandillo et al., "fw2.2: a quantitative trait locus key to the evolution of tomato fruit size," Science, vol. 289 , no. 5476, pp. 85-88, 2000. 

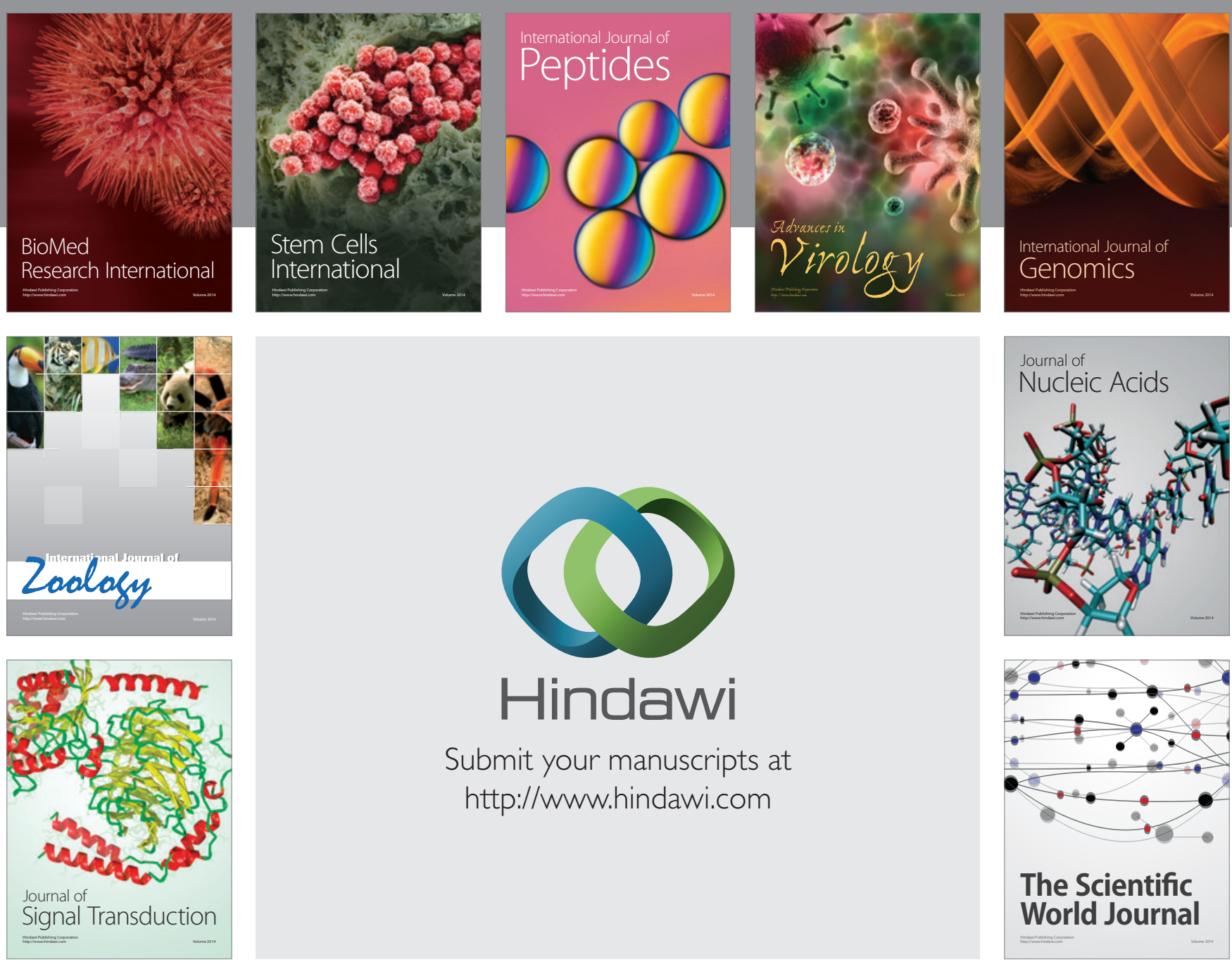

Submit your manuscripts at

http://www.hindawi.com
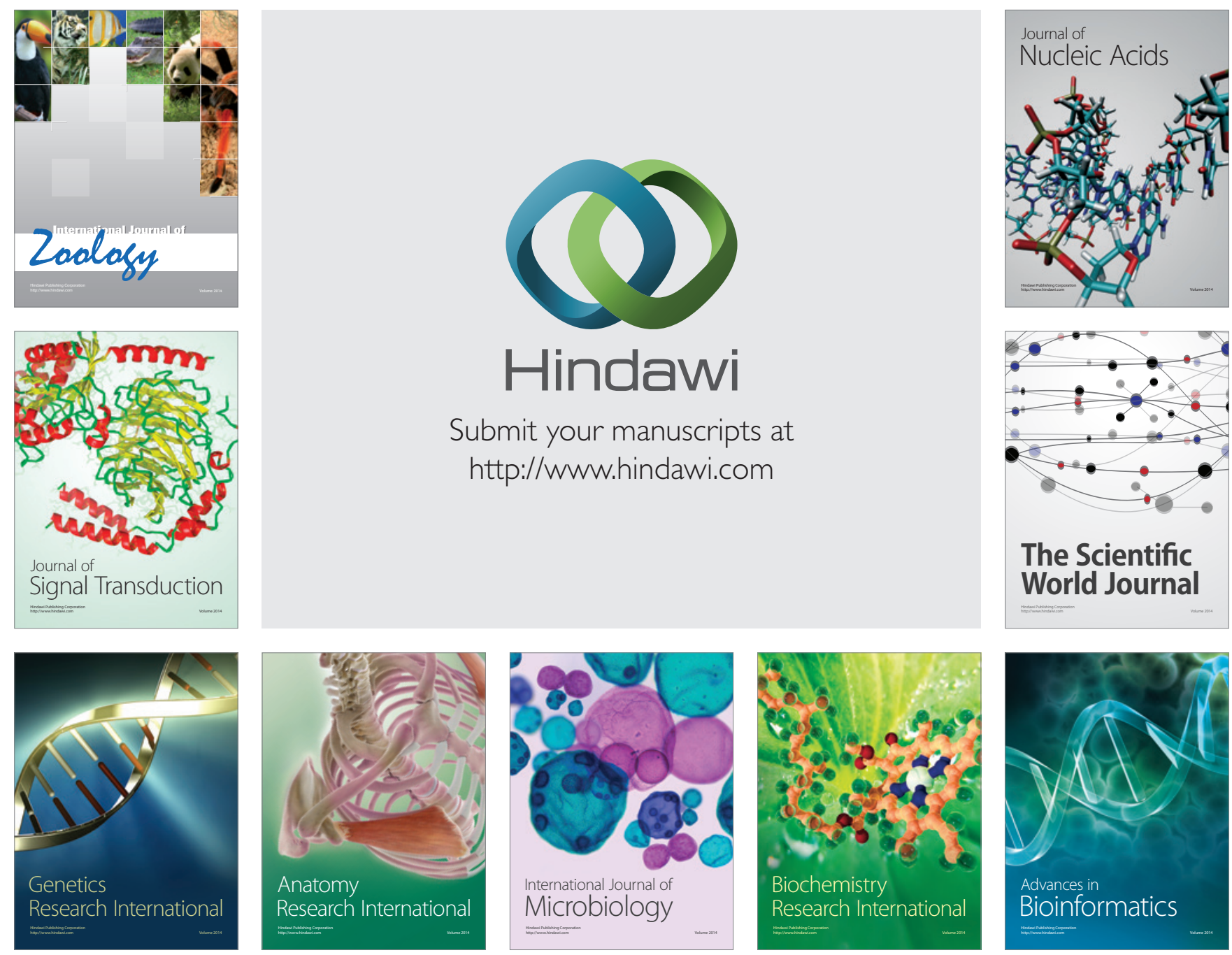

The Scientific World Journal
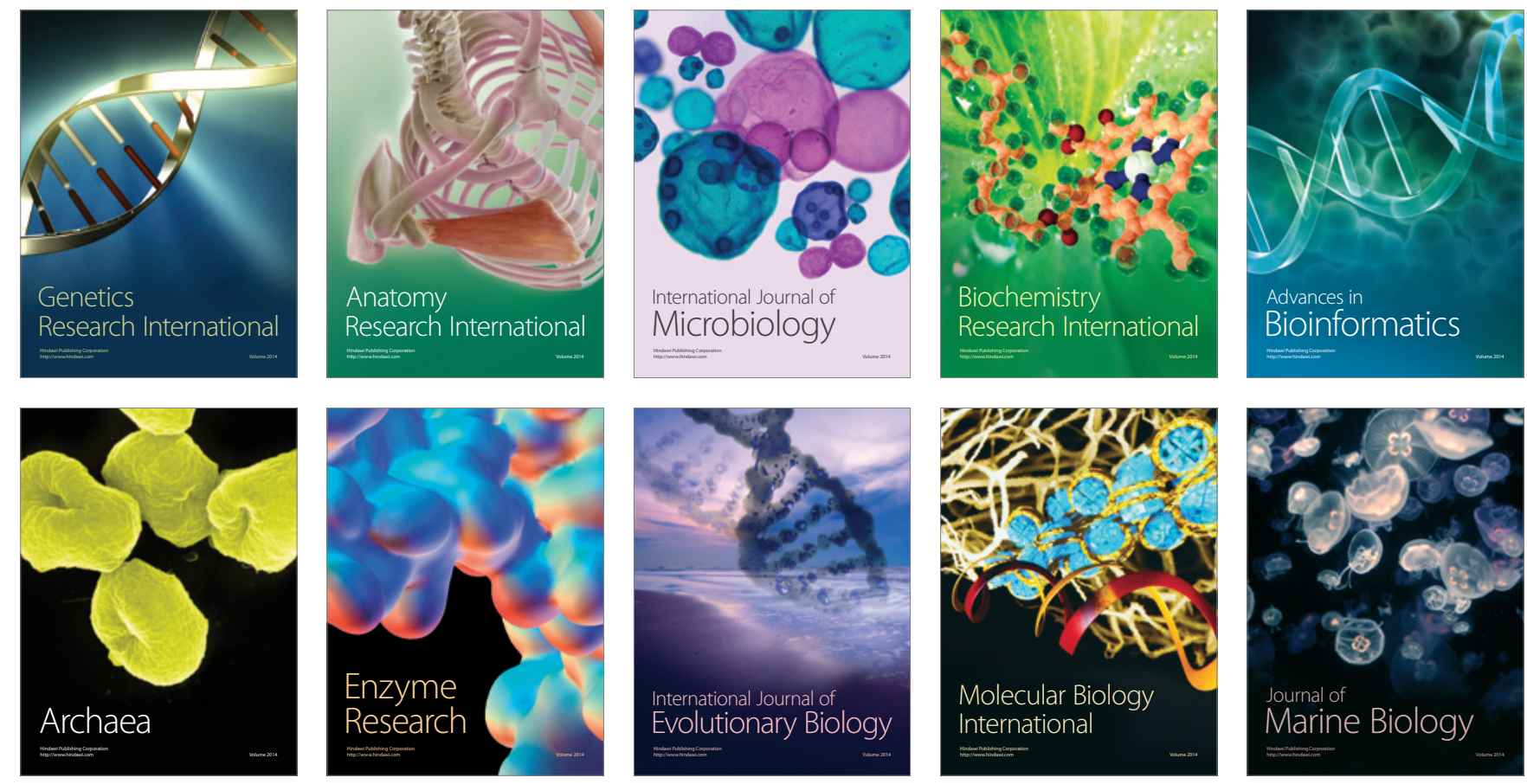